\title{
STRENGTH BEHAVIOR OF EXPANSIVE SOIL DEPOSIT DUE TO DIFFUSION OF CALCIUM CHLORIDE SOLUTION
}

\author{
S. P. Lajurkar \\ Department of Civil \\ Ph.D Scholar, Y. C.C.E., \\ Nagpur, M.S., India
}

\author{
Dr. Y. S. Golait \\ Department of Civil \\ Ex. Prof. Emeritus, Y. C.C.E., \\ Nagpur, M.S., India
}

\author{
Dr. S. R. Khandeshwar \\ Department of Civil \\ Prof. Y. C.C.E., \\ Nagpur, M.S., India
}

Abstract - Many investigators in the past have found that chemicals like calcium chloride, potassium chloride, sodium silicate, ferric chloride etc. are effective in expansive soil improvement. Extensive work is done on calcium chloride as admixture in expansive soil for its use as construction material. In the present domain of in-situ ground improvement study calcium chloride is used as this chemical is highly soluble in water, it is economical and also is easily available everywhere. From practice point of view the main aspects of importance are increase in the bearing capacity and stiffness of the ground. The present research paper focuses on the possibility of in-situ ground improvement with respect to increase in strength by chemical diffusion in the actual ground condition. The characteristics of chemical with respect to concentration may affect the ground improvement by diffusion technique. In order to arrive, at the optimum dose of calcium chloride solution for in-situ improvement of soft clay deposit, it was thought to study soft clay soil behavior due to diffusion of calcium chloride solution with different concentrations. In the field conditions, the wetness of the soil mass from the surface to a greater depth below the surface is varying due to seasonal cyclic variation i.e. rainy to summer season and summer to rainy season. This variation of moisture content regime is also incorporated in the present study to decide upon the suitable time for ground improvement by chemical diffusion. Similarly natural expansive soil deposit found in India at different location has the different degree of swellability, may also affect the degree of improvement of natural expansive ground characteristics. Hence this variation of degree of swellability of soil also incorporated. Under the lab test condition the percentage increase in strength for soil having higher degree of swellability with low up to $147 \%$ was observed due to diffusion of calcium chloride solution.

Keywords - expansive soil deposit; percentage strength improvement (PSI), improvement by diffusion technique, calcium chloride, degree of swellability, swelling behavior

\section{INTRODUCTION}

In India $20 \%$ of the total area of the country is covered with expansive soil deposit. This expansive soil is considered as the most problematic and treacherous as construction as well as foundation material because of its low bearing capacity, high compressibility and high volumetric changes during dry-wet seasons (Chen 2012, Katti 1978, Petry \& Little 2002). Many researchers and investigators have developed various approaches and methods of improving the undesirable characteristics of the expansive soil. The widely popular method of using of admixtures, like fly ash, lime, cement, chemicals, randomly distributed geosynthetic fibers and many waste materials etc. is found to be effective in this respect (Katti 1978, Petry \& Little 2002, Carreon Delfin G. et al. 2006, Cokca 2001, Aparna, et al., 2014, Kamon \& Nontananandh 1991, Nalbantoglu 2006). However, in the majority of the geotechnical construction problems one has to face with the construction on natural grounds in which case soil functions as a foundation material. Thus, the in-situ improvement in expansive soil characteristics by any possible ground improvement technique is of utmost importance in civil engineering construction activities in expansive soil areas. It may be realized that this category of field construction is of widespread nature as compared to problems where the soil is used as construction material. Some of the probable methods for ensuring the trouble-free performance of the structures on expansive soil are the use of under reamed piles, provision of CNS layers or alternate cushions of other specified materials, granular anchor piles (GPA), use of stone columns, sand piles etc (Katti 1978, Petry \& Little 2002, Aparna, et al. 2014, Mohan, D., Jain, G. S. and Sharma, D. 1973. Murty, V. R. and Praveen, G. V. 2008 Phanikumar, B. R., Sharma, R. S., Rao, A. S. and Madhav, M. R. 2004, Sawant,V., Kumar, A. P. and Ranjan, G. 2010).

Expansive soil being clayey soil, techniques like grouting etc. is not feasible for the purpose. Though various admixtures like lime, cement, fly ash etc. are very effective in soil improvement their use in in-situ ground improvement is practically impossible (Katti 1978, Petry \& Little 2002, Carreon D. G. et al. 2006, Cokca 2001, Aparna, et al., 2014, 


\section{International Journal of Engineering Applied Sciences and Technology, 2019 \\ Vol. 4, Issue 1, ISSN No. 2455-2143, Pages 67-77 \\ Published Online May 2019 in IJEAST (http://www.ijeast.com)}

Kamon \& Nontananandh 1991, Nalbantoglu 2006). However, the use of water soluble chemicals is considered feasible in this respect (J. G. Khun 1970, Murty, V. R. and Krishna, P. H. 2006, Murthy, V. R. and Hari Krishna, P. 2007). Unfortunately, the review of literature reveals that this aspect of in-situ ground improvement of expansive soil by use of admixtures in the form of chemical solutions has remained almost inadequately investigated. Very limited work of preliminary nature with limited objectives is reported in the literature. The present work focuses on contributing to some extent in this inadequately investigated domain of in-situ improvement of expansive clay sites by diffusion of chemical solutions.

\section{PRINCIPLE AND BASIC CONCEPTS}

It is realized that the 'In-situ' expansive clay has certain water imbibing capacity of varying magnitude depending on its initial water content. Expansive clay with its electrochemical activity exhibits certain osmotic pressure and water suction characteristics. Water thus diffuses in to the soil mass in a definite zone surrounding the point of water supply source. It is thought that water soluble chemical may also enter in to the soil body if it is diffused in to it. The diffused chemical solution after entering in to the soil mass may interact with the electrochemically active clay particles of expansive soil thereby altering its characteristics with respect to strength, compressibility, stiffness and swell-shrink nature. It is of great interest to reveal to certain reasonable extent the various aspects of the effects of diffused chemical solution on native expansive soil mass. The present study involves these considerations.

\section{LABORATORY INVESTIGATIONS}

Laboratory investigations were carried out on four artificially prepared soils with different swelling characteristics to study the effect of calcium chloride solution on swelling behavior of soil with different initial physical state. This scheme of the investigations was devised with the consideration that any 'In-situ' soil deposit at site may have different degree of swellability and also depending on the level below ground surface the soil may possess different initial water content condition in various seasons. Details of the material used, methodology of various test conducted during investigations are as below.

\section{A. Materials Used-}

\section{Black Cotton Soil}

In India the swelling soils which cover about $20 \%$ of the total area of the country are colloquially called as black cotton soils because of their black color and fertility to grow cotton crop in abundance. This black cotton soil was collected from the site in the neighborhood of Nagpur city of India by method of disturbed sampling after removing the top layer of soil upto1m depth. Collected soil transported in sacks to the laboratory.

For further use the soil was air dried, pulverized and sieved with Indian Standard sieve as per requirement of laboratory investigation program.

\section{Bentonite}

Commercial grade Bentonite available in the local market was used for preparing soil mixes with higher swelling characteristic by mixing with native Black Cotton soil.

\section{NSS}

Non swelling soil (NSS) having least swellability characteristic was used to prepare soil mix of lowest swellability. In ancient India this soil was used for construction of Gadhi's or Haveli's of rich person. NS soil was collected from the Gadhi present over an area near Pawnar, Nagpur Road with due permission of local people and transported in sacks to the laboratory (Kondekar, et al. 2013).

\section{Calcium chloride $\left(\mathrm{CaCl}_{2}\right)$}

Commercially available calcium chloride $\left(\mathrm{CaCl}_{2}\right)$ was selected for the study. It consisted of $72.79 \%$ calcium chloride $\left(\mathrm{CaCl}_{2}\right),<0.1 \%$ magnesium chloride $\left(\mathrm{MgCl}_{2}\right)$ and $27.21 \%$ water $\left(\mathrm{H}_{2} \mathrm{O}\right)$.

Many investigators have established the effectiveness of calcium chloride for stabilization of soil when the soil is to be used as construction material (Phanikumar, et al. 1998, Kesava \& Prasada Raju 2011). Calcium chloride is essentially water retentive in mechanically stabilized bases and surfacing. Being hygroscopic and deliquescent the salt absorbs moisture from the atmosphere and retains it. It is highly soluble in water and calcium cations can easily replace other adsorbed cations in the adsorption complex of clay particles thereby facilitating the Base Exchange phenomenon to take place. It lowers the vapor pressure and increases the surface tension. Besides, it acts as soil flocculent (Golait, et al. 2012).

\section{B. Preparation of Soil Mixes-}

The main focus of the present study is the 'In-situ' condition of the soil deposit in untreated state and the treated state. In order to simulate such field situation of the ground in the laboratory, sample preparation was done by adopting a procedure as described here under.

Natural soil with the finer active fraction (F) may also possess the swellability characteristics of different magnitude. Considering the varying degree of swellability of finer fraction (F) various mixes were prepared by adding different percentage of Bentonite and NS soil as shown in Table 1. In this way finer fraction (F) material with $40 \%$ Bentonite and $60 \%$ of $2 \mathrm{~mm} \mathrm{BC}$ soil fraction is considered as fine active fraction with largest swellability, whereas finer fraction $(\mathrm{F})$ containing $20 \% 2 \mathrm{~mm}$ NS soil and $80 \%$ of $2 \mathrm{~mm} \mathrm{BC}$ soil fraction is considered have least swellable material. 
Table 1 Composition of soil mixes

\begin{tabular}{|c|c|l|}
\hline Sr. No. & Mix & \multicolumn{1}{|c|}{ Designation } \\
\hline 1 & A & $\mathbf{6 0 \%}$ BCS+40\% Bentonite \\
\hline 2 & B & $\mathbf{8 0 \%}$ BCS+20\% Bentonite \\
\hline 3 & C & $\mathbf{1 0 0 \%}$ BCS \\
\hline 4 & D & $\mathbf{8 0 \%}$ BCS+20\% NSS \\
\hline
\end{tabular}

\section{Characterization of Soil Investigated-}

All geotechnical tests were performed on these four artificially prepared soil mixes to categorize expansivity of the soils. The tests include the specific gravity, Atterberg's limit, free swell index (FSI), free swell ratio (FSR) and $\mathrm{pH}$ of the soil. The physical properties of these four mixes and there classification is given in Table 2. All these physical properties were assessed using methods given in different parts of Indian Standards (IS 2720).

Table 2 Physical properties of soil mixes

\begin{tabular}{|c|c|c|c|c|c|}
\hline \multirow{2}{*}{$\begin{array}{c}\text { Physical } \\
\text { Properties }\end{array}$} & \multicolumn{5}{|c|}{ Soil Mix Category } \\
\hline & & $\mathbf{A}$ & B & $\mathrm{C}$ & D \\
\hline Liquid limit & $\mathrm{w}_{\mathrm{L}}(\%)$ & 82.65 & 71.65 & $\mathbf{5 8 . 8 0}$ & 55.4 \\
\hline Plastic Limit & $\mathrm{W}_{\mathrm{P}}(\%)$ & 44.29 & 40.75 & 33.16 & 31.8 \\
\hline $\begin{array}{l}\text { Plasticity } \\
\text { Index }\end{array}$ & $\mathbf{I}_{\mathrm{P}}(\%)$ & 38.36 & 30.91 & 25.64 & 24.32 \\
\hline $\begin{array}{l}\text { Shrinkage } \\
\text { Limit }\end{array}$ & $\mathrm{w}_{\mathrm{S}}(\%)$ & 9.90 & 11.03 & 12.29 & 13.81 \\
\hline $\begin{array}{l}\text { Free Swell } \\
\text { Ratio }\end{array}$ & FSR & 4.314 & 3.89 & 2.522 & 1.423 \\
\hline $\begin{array}{l}\text { Free Swell } \\
\text { Index }\end{array}$ & FSI\% & 83 & 58 & 39 & 28 \\
\hline $\begin{array}{l}\text { Specific } \\
\text { gravity }\end{array}$ & G & 2.6 & 2.68 & 2.71 & 2.53 \\
\hline pH value & & 7.79 & 7.38 & 7.06 & 7.57 \\
\hline $\begin{array}{l}\text { Degree of } \\
\text { Expansivity }\end{array}$ & & $\begin{array}{l}\text { Very } \\
\text { High }\end{array}$ & $\begin{array}{l}\text { Very } \\
\text { High }\end{array}$ & High & Moderate \\
\hline Classification & & $\mathbf{C H}$ & CH & $\mathbf{C H}$ & $\mathbf{C H}$ \\
\hline
\end{tabular}

It is clearly seen from above values of various property parameters that the soil $\mathrm{A}$ is of highest swellability among these soils and soil D is of lowest swellability. The continuous decrease in swellability is exhibited in the following order $\mathrm{A} \rightarrow \mathrm{B} \rightarrow \mathrm{C} \rightarrow \mathrm{D}$. As per this sequence of soil type the values of liquid limit $\left(\mathrm{w}_{\mathrm{L}}\right)$, plastic soil $\left(\mathrm{I}_{\mathrm{P}}\right)$, free swell index (FSI) and free swell ratio (FSR), show gradual decrease.

\section{Sample Preparation-}

Each soil mix as stated in Table 1 were firstly oven dried for 1 hour to remove moisture content due to atmospheric condition and then kept for cooling in desiccators for 15 minutes. After completion of cooling process soil mixed with water to attain its water content at approximately midway between its plastic limit $\left(\mathrm{w}_{\mathrm{p}}\right)$ and liquid limit $\left(\mathrm{w}_{\mathrm{L}}\right)$. The quantity of water for each soil mix was calculated from the liquid limit and plastic limit value as indicated in Table 2. Wet mass was kept in airtight plastic bag for minimum ten hours for uniform distribution of water. For getting identical wet cylindrical soil samples, PVC pipe of $8 \mathrm{~cm}$ diameter was cut in to number of pieces of $12 \mathrm{~cm}$ height and use for sample preparation. Grease was applied on inner side of each PVC pipe sampler tube so that wet soil mass easily extruded after shrinking. Wet soil was then pressed into eighteen PVC open ended tubes and kept for air drying. After completion of 2 days of drying, sampler tube is removed and samples are allowed to dry. All the samples were air dried in shade, making them upside down frequently. It was observed, those wet soil samples were laterally bulge due to self weight and wet condition of soil. Hence all the samples were wrapped with perforated transparency sheet and tightened with rubber. Drying of initially fully saturated plastic soil sample caused its gradual shrinking (without development of cracks within) and consequent reduction in its water content and the degree of saturation. It was observed from few pilot tests of sample drying that 5 days air drying brought the water content of the sample to $75 \%, 36 \%, 29 \%$ and $25 \%$ while 10 days and 15 days drying lowered down the water content to $47 \%, 26 \%$, $21 \%, 15 \%$ and $26 \%, 20 \%, 15 \%$ and $9 \%$ for soil mixes $\mathrm{A}(60 \% \mathrm{BCS}+40 \%$ Bentonite $), \quad \mathrm{B}(80 \% \mathrm{BCS}+20 \%$ Bentonite $)$, $\mathrm{C}(100 \% \mathrm{BCS})$ and $\mathrm{D}(80 \% \mathrm{BCS}+20 \% \mathrm{NSS})$ respectively. These values of water content for the soil under investigation pertained to water content near-saturation state, near-OMC state and near-natural dry condition respectively of field soil deposit. Total eighteen wet samples were prepared for each soil mix; six samples of each soil mix (Series 1) were dried for 5 days. Remaining twelve samples were dried for 10 days (Series 2) and 15 days (Series 3) respectively. This procedure formed the shrunken cylindrical samples. Out of the six samples in each series one was tested for determining its initial water content. The remaining five were kept for diffusion of fluids i.e. water, and calcium chloride $\left(\mathrm{CaCl}_{2}\right)$ solution of $1 \%, 1.5 \%, 2 \%$ and $3 \%$ concentration for 10 days. After completion of diffusion process samples were tested for Unconfined compressive strength test to study the strength and stiffness behavior.

\section{E. Strength Behavior Test-}

To study strength behavior of soil samples after diffusion of water/ calcium chloride solution, unconfined compressive strength was conducted on the sample at the end of diffusion process. At the end of the 10 days of diffusion samples were removed with a great care from the diffusion jacket. After removing circumferential wrapping of samples; diameter, height and weight of the sample were measured and final water content $\left(\mathrm{w}_{\mathrm{f}}\right)$, bulk unit weight $(\gamma)$ and dry unit weight $\left(\gamma_{\mathrm{d}}\right)$ were determined. All the samples were then tested for determination unconfined compressive strength (UCS) by subjecting to a steady increasing axial compressive force at a strain rate of $1.25 \mathrm{~mm} / \mathrm{min}$ as per IS: 2720 until failure occurs 
by unconfined compression testing machine. Stress, stiffness and strain at failure are determined from this test.

Photographs showing placement and loading of sample on unconfined compressive strength machine and failure of sample during UCS are given Figure 1.

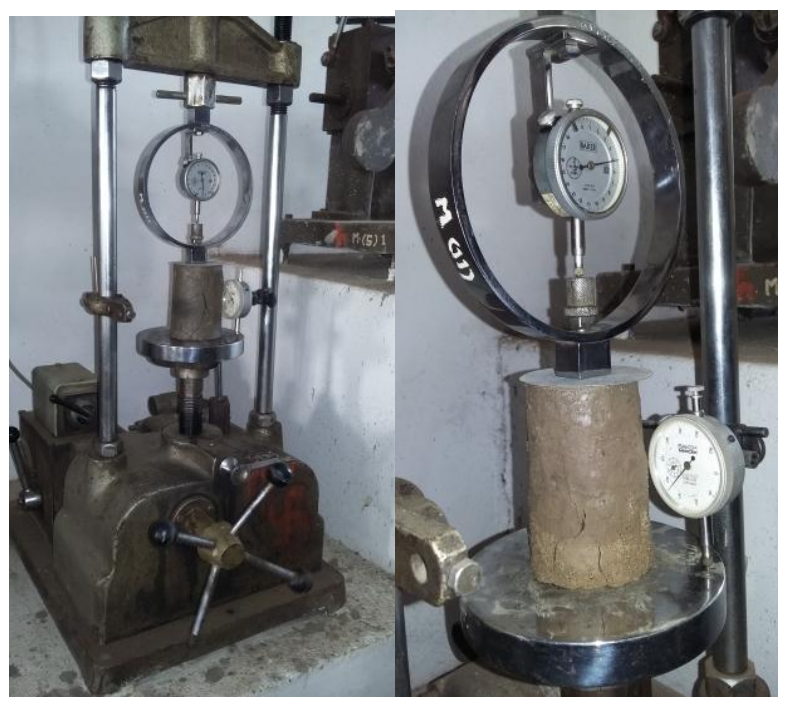

Fig 1. Placement and loading of sample on unconfined compressive strength machine and failure of sample during UCS.

\section{RESULTS AND INTERPRETATION}

\section{A. Stress-Strain Behavior-}

Unconfined compressive strength test was conducted on samples of all soil of varying degree of swellability after completion of 10 days diffusion process. The stress-strain behavior of each sample during test was observed and plotted in Figure 2.

From the stress-strain curves, it is observed that the behavior of soil samples during diffusion is affected greatly due to the concentration of calcium chloride solution, degree of swellability and initial water content of soil samples. The stress-strain curves of each soil shows that higher the initial water content of soil mass, lower is the failure stress. As well as examination of the stress-strain curves indicates that the failure stress is depends on the concentration of calcium chloride solution and it increases with the increase in the concentration of calcium chloride solution up to $2 \%$. For $3 \%$ concentration the value of stress at failure for soil sample is found to be decrease.

The nature of the stress-strain curves is found to be similar for all the soil samples. Initially the curve is linear, then stress is increases in curve nature up to a failure point and thereafter it decreased. The failure stress at peak point of stress-strain curve is reported as strength. The behavior of strength of all four categories of soil with different initial water content caused due to diffusion of calcium chloride solution of different concentration is discussed hereunder.

\section{B. Strength Behavior-}

Unconfined compressive strength (UCS in $\mathrm{kPa}$ ) of each sample of all four soils with different degree of swellability is determined. Then percentage strength improvement (PSI) is determined for soil samples treated by calcium chloride solution of different concentrations, considering the UCS of soil sample diffused by water as the base. These so determined UCS and PSI are presented in Table 3. The initial dry unit weight of soil samples $\left(\gamma_{\mathrm{di}}\right)$ before diffusion and final dry unit weight of soil samples $\left(\gamma_{\mathrm{df}}\right)$ after completion of diffusion process are determined and presented in Table 3.

Table 3: Results of UCS tests

Soil A (60\%BCS+40\%Bentonite)

\begin{tabular}{|c|c|c|c|c|c|c|c|}
\hline $\begin{array}{l}\text { Diffusing } \\
\text { fluid }\end{array}$ & $\begin{array}{l}\mathrm{W}_{\mathrm{i}} \\
(\%)\end{array}$ & $\begin{array}{l}\mathrm{W}_{\mathrm{f}} \\
(\%)\end{array}$ & $\begin{array}{l}\Delta \mathrm{W} \\
(\%)\end{array}$ & $\begin{array}{c}\gamma \mathrm{d}_{\mathrm{i}} \\
\mathrm{gm} / \mathrm{cc}\end{array}$ & $\begin{array}{c}\gamma \mathrm{d}_{\mathrm{f}} \\
\mathrm{gm} / \mathrm{cc}\end{array}$ & $\begin{array}{l}\mathrm{UCS} \\
\mathrm{kPa}\end{array}$ & PSI \\
\hline Water & \multirow{5}{*}{74.47} & 85.15 & 10.7 & 0.84 & 0.78 & 15.27 & 0 \\
\hline 1.0 & & 82.39 & 7.9 & 0.85 & 0.80 & 19.95 & 31 \\
\hline 1.5 & & 80.72 & 6.2 & 0.85 & 0.82 & 24.89 & 63 \\
\hline 2.0 & & 79.06 & 4.6 & 0.85 & 0.82 & 25.26 & 65 \\
\hline 3.0 & & 83.03 & 8.6 & 0.85 & 0.80 & 19.79 & 30 \\
\hline Water & \multirow{5}{*}{46.77} & 84.42 & 37.6 & 1.11 & 0.80 & 12.88 & 0 \\
\hline 1.0 & & 66.21 & 19.4 & 1.12 & 0.95 & 19.83 & 54 \\
\hline 1.5 & & 60.00 & 13.2 & 1.12 & 0.99 & 23.89 & 85 \\
\hline 2.0 & & 57.00 & 10.2 & 1.12 & 1.03 & 24.06 & 87 \\
\hline 3.0 & & 63.67 & 16.9 & 1.11 & 0.97 & 21.68 & 68 \\
\hline Water & \multirow{5}{*}{25.45} & 83.91 & 58.5 & 1.47 & 0.79 & 8.79 & 0 \\
\hline 1.0 & & 59.60 & 34.1 & 1.47 & 1.01 & 17.04 & 94 \\
\hline 1.5 & & 55.84 & 30.4 & 1.47 & 1.06 & 19.48 & 122 \\
\hline 2.0 & & 54.22 & 28.8 & 1.47 & 1.08 & 21.71 & 147 \\
\hline 3.0 & & 60.34 & 34.9 & 1.47 & 0.99 & 19.25 & 119 \\
\hline
\end{tabular}

Soil B (80\%BCS+20\%Bentonite)

\begin{tabular}{|c|c|c|c|c|c|c|c|}
\hline $\begin{array}{l}\text { Diffusin } \\
\text { g fluid }\end{array}$ & $\begin{array}{l}\mathrm{W}_{\mathrm{i}} \\
(\%)\end{array}$ & $\begin{array}{l}\mathrm{W}_{\mathrm{f}} \\
(\%)\end{array}$ & $\begin{array}{l}\Delta \mathrm{W} \\
(\%)\end{array}$ & $\begin{array}{c}\gamma \mathrm{d}_{\mathrm{i}} \\
\mathrm{gm} / \mathrm{c} \\
\mathrm{c}\end{array}$ & $\begin{array}{c}\gamma \mathrm{d}_{\mathrm{f}} \\
\mathrm{gm} / \mathrm{cc}\end{array}$ & $\begin{array}{l}\mathrm{UCS} \\
\mathrm{kPa}\end{array}$ & PSI \\
\hline Water & \multirow{5}{*}{36.40} & 44.11 & 7.71 & 1.30 & 1.22 & 35.68 & 0 \\
\hline 1.0 & & 41.44 & 5.04 & 1.32 & 1.26 & 46.01 & 29 \\
\hline 1.5 & & 40.00 & 3.60 & 1.30 & 1.27 & 52.35 & 47 \\
\hline 2.0 & & 39.60 & 3.20 & 1.30 & 1.27 & 56.87 & 59 \\
\hline 3.0 & & 40.45 & 4.05 & 1.30 & 1.25 & 47.29 & 33 \\
\hline Water & \multirow{5}{*}{25.93} & 44.83 & 18.90 & 1.51 & 1.20 & 24.92 & 0 \\
\hline 1.0 & & 39.55 & 13.63 & 1.49 & 1.30 & 37.30 & 50 \\
\hline 1.5 & & 36.50 & 10.57 & 1.50 & 1.34 & 44.21 & 77 \\
\hline 2.0 & & 35.56 & 9.63 & 1.50 & 1.36 & 44.41 & 78 \\
\hline 3.0 & & 38.08 & 12.16 & 1.50 & 1.32 & 38.35 & 54 \\
\hline Water & \multirow{5}{*}{19.52} & 44.89 & 25.37 & 1.68 & 1.19 & 15.97 & 0 \\
\hline 1.0 & & 36.55 & 17.03 & 1.68 & 1.35 & 25.08 & 57 \\
\hline 1.5 & & 33.59 & 14.07 & 1.68 & 1.41 & 30.86 & 93 \\
\hline 2.0 & & 31.86 & 12.34 & 1.67 & 1.45 & 31.93 & 100 \\
\hline 3.0 & & 35.53 & 16.01 & 1.67 & 1.35 & 23.33 & 46 \\
\hline
\end{tabular}


Soil C (100\%BCS)

\begin{tabular}{|c|c|c|c|c|c|c|c|}
\hline $\begin{array}{c}\text { Diffusing } \\
\text { fluid }\end{array}$ & $\begin{array}{c}\mathrm{W}_{\mathrm{i}} \\
(\%)\end{array}$ & $\begin{array}{l}\mathrm{W}_{\mathrm{f}} \\
(\%)\end{array}$ & $\begin{array}{l}\Delta \mathrm{W} \\
(\%)\end{array}$ & $\begin{array}{c}\gamma \mathrm{d}_{\mathrm{i}} \\
\mathrm{gm} / \mathrm{cc}\end{array}$ & $\begin{array}{c}\gamma \mathrm{d}_{\mathrm{f}} \\
\mathrm{gm} / \mathrm{cc}\end{array}$ & $\begin{array}{l}\mathrm{UCS} \\
\mathrm{kPa}\end{array}$ & PSI \\
\hline Water & \multirow{5}{*}{28.60} & 34.72 & 6.12 & 1.48 & 1.42 & 48.73 & 0 \\
\hline 1.0 & & 33.21 & 4.61 & 1.48 & 1.44 & 55.07 & 13 \\
\hline 1.5 & & 32.04 & 3.44 & 1.48 & 1.45 & 58.88 & 21 \\
\hline 2.0 & & 31.20 & 2.61 & 1.48 & 1.42 & 60.00 & 23 \\
\hline 3.0 & & 32.73 & 4.13 & 1.48 & 1.40 & 53.82 & 10 \\
\hline Water & \multirow{5}{*}{21.08} & 34.56 & 13.48 & 1.65 & 1.48 & 40.72 & 0 \\
\hline 1.0 & & 30.87 & 9.79 & 1.65 & 1.50 & 53.13 & 30 \\
\hline 1.5 & & 29.23 & 8.15 & 1.65 & 1.52 & 57.56 & 41 \\
\hline 2.0 & & 28.15 & 7.07 & 1.65 & 1.46 & 58.38 & 43 \\
\hline 3.0 & & 31.25 & 10.17 & 1.65 & 1.40 & 47.55 & 17 \\
\hline Water & \multirow{5}{*}{14.64} & 34.45 & 19.81 & 1.77 & 1.49 & 26.96 & 0 \\
\hline 1.0 & & 29.94 & 15.29 & 1.77 & 1.55 & 37.70 & 40 \\
\hline 1.5 & & 26.16 & 11.52 & 1.77 & 1.56 & 41.56 & 54 \\
\hline 2.0 & & 25.74 & 11.09 & 1.77 & 1.48 & 42.27 & 57 \\
\hline 3.0 & & 29.89 & 15.25 & 1.77 & 1.42 & 32.95 & 22 \\
\hline
\end{tabular}

Soil D (80\%BCS+20\%NSS)

\begin{tabular}{|c|c|c|c|c|c|c|c|}
\hline $\begin{array}{l}\text { Diffusing } \\
\text { fluid }\end{array}$ & $\begin{array}{l}\mathrm{W}_{\mathrm{i}} \\
(\%)\end{array}$ & $\begin{array}{l}\mathrm{W}_{\mathrm{f}} \\
(\%)\end{array}$ & $\begin{array}{l}\Delta \mathrm{W} \\
(\%)\end{array}$ & $\begin{array}{c}\gamma \mathrm{d}_{\mathrm{i}} \\
\mathrm{gm} / \mathrm{cc}\end{array}$ & $\begin{array}{c}\gamma \mathrm{d}_{\mathrm{f}} \\
\mathrm{gm} / \mathrm{cc}\end{array}$ & $\begin{array}{l}\mathrm{UCS} \\
\mathrm{kPa}\end{array}$ & PSI \\
\hline Water & \multirow[t]{5}{*}{25.38} & 32.09 & 6.71 & 1.45 & 1.38 & 54.02 & 0 \\
\hline 1.0 & & 30.74 & 5.37 & 1.46 & 1.39 & 58.05 & 7 \\
\hline 1.5 & & 30.14 & 4.76 & 1.46 & 1.40 & 59.95 & 11 \\
\hline 2.0 & & 30.20 & 4.83 & 1.46 & 1.40 & 61.16 & 13 \\
\hline 3.0 & & 30.58 & 5.21 & 1.46 & 1.40 & 58.45 & 8 \\
\hline Water & \multirow[t]{5}{*}{15.26} & 31.61 & 16.35 & 1.62 & 1.39 & 46.65 & 0 \\
\hline 1.0 & & 28.70 & 13.44 & 1.62 & 1.43 & 50.42 & 8 \\
\hline 1.5 & & 27.34 & 12.08 & 1.62 & 1.46 & 53.61 & 15 \\
\hline 2.0 & & 27.27 & 12.01 & 1.62 & 1.47 & 53.90 & 16 \\
\hline 3.0 & & 27.76 & 12.50 & 1.62 & 1.45 & 50.46 & 8 \\
\hline Water & \multirow[t]{5}{*}{8.69} & 31.60 & 22.91 & 1.75 & 1.39 & 27.32 & 0 \\
\hline 1.0 & & 28.30 & 19.61 & 1.75 & 1.46 & 31.11 & 14 \\
\hline 1.5 & & 25.46 & 16.77 & 1.76 & 1.51 & 34.08 & 25 \\
\hline 2.0 & & 24.63 & 15.94 & 1.75 & 1.52 & 35.21 & 29 \\
\hline 3.0 & & 26.42 & 17.73 & 1.75 & 1.48 & 30.96 & 13 \\
\hline
\end{tabular}

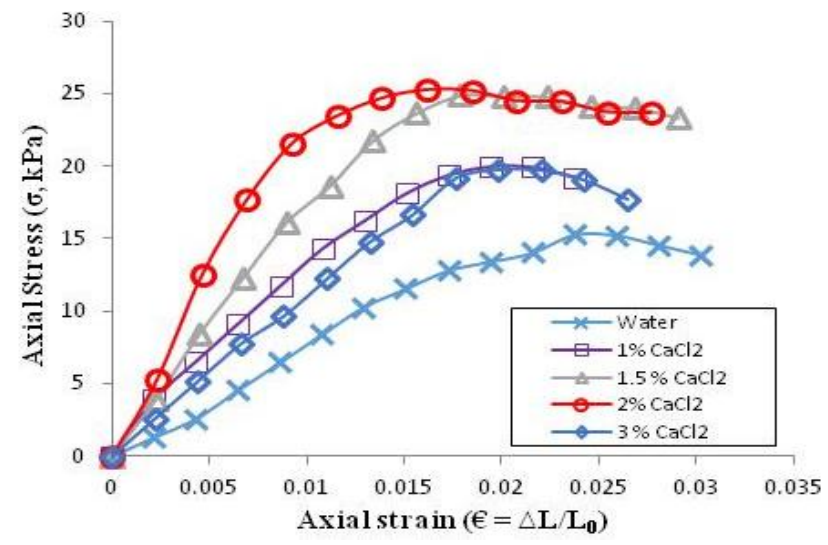

(a) Soil A (60\% BCS $+40 \%$ Bentonite) at $\mathrm{w}_{\mathrm{i}}=74.47 \%$

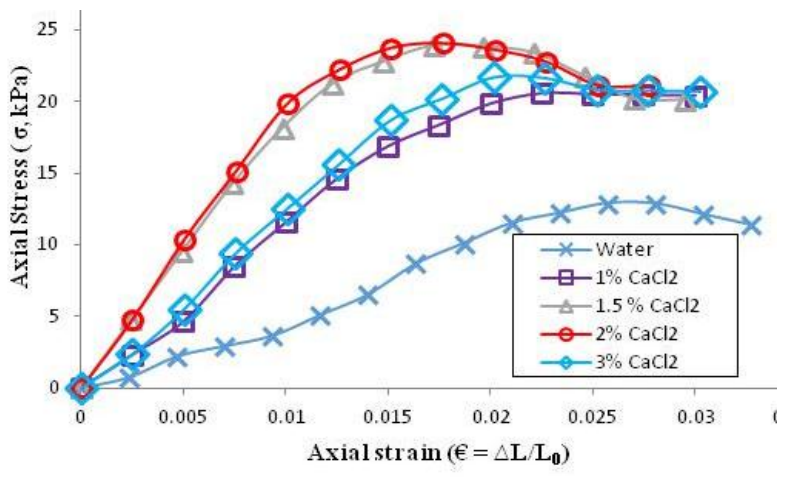

b) Soil A (60\% BCS+40\%Bentonite) at $\mathrm{w}_{\mathrm{i}}=46.77 \%$

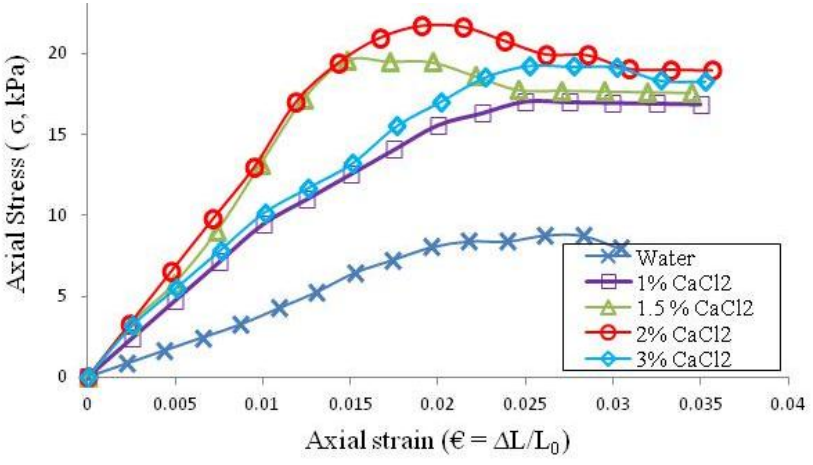

c) Soil A $(60 \% \mathrm{BCS}+40 \%$ Bentonite $)$ at $\mathrm{w}_{\mathrm{i}}=25.45 \%$

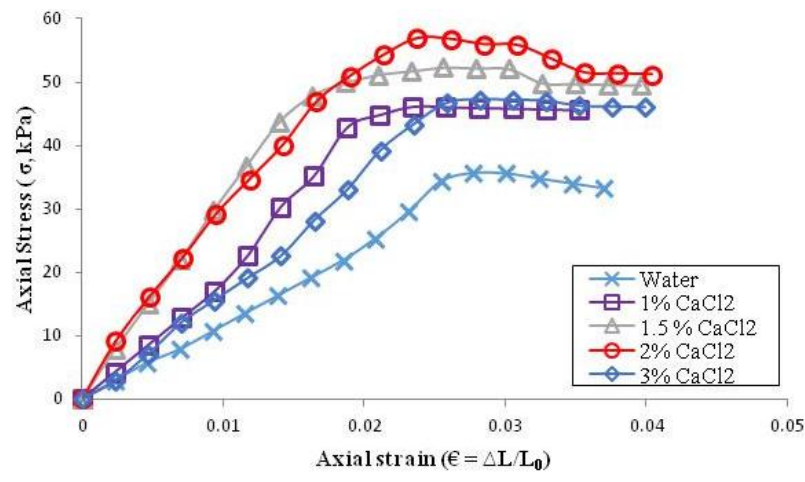

d) Soil B ( $80 \% \mathrm{BCS}+20 \%$ Bentonite $)$ at $\mathrm{w}_{\mathrm{i}}=36.40 \%$

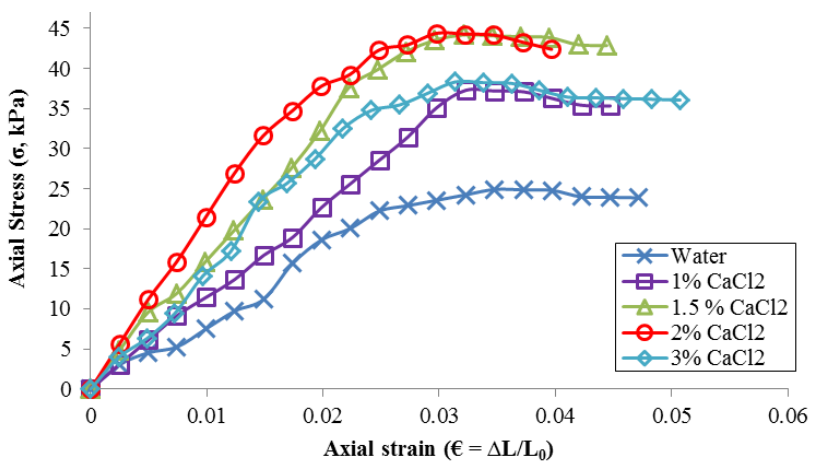

e) Soil B ( $80 \% \mathrm{BCS}+20 \%$ Bentonite $) \mathrm{w}_{\mathrm{i}}=25.93 \%$ 


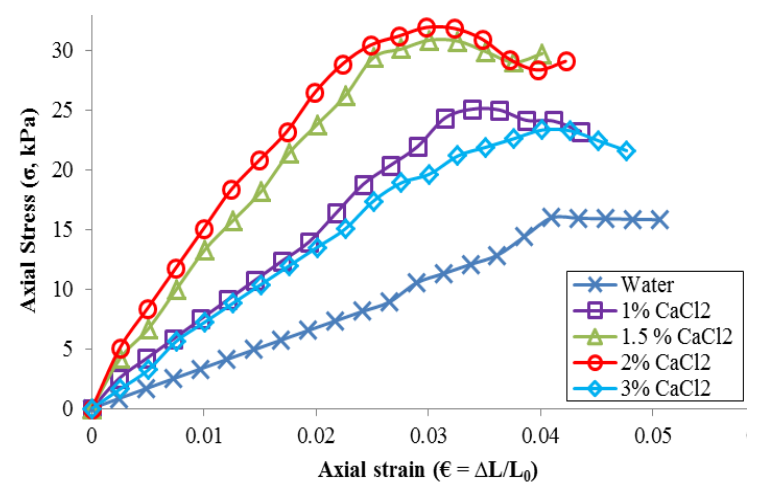

f) Soil B $(80 \% \mathrm{BCS}+20 \%$ Bentonite $) \mathrm{w}_{\mathrm{i}}=19.52 \%$

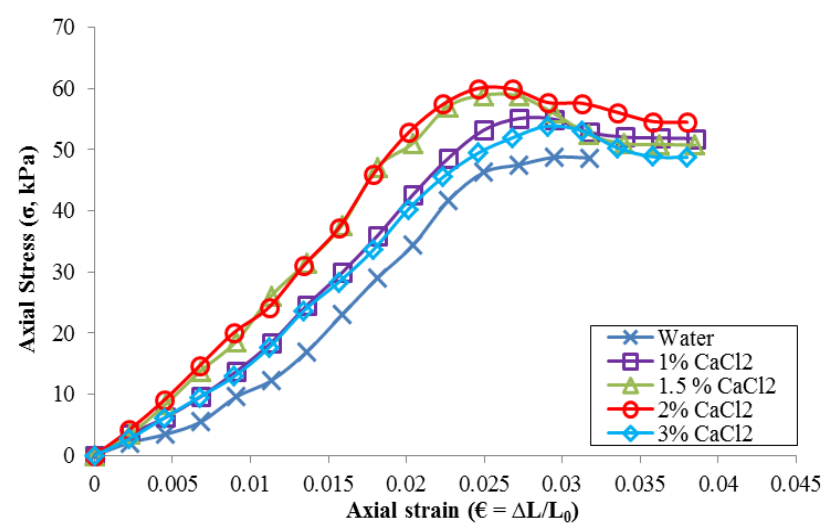

g) Soil C (100\%BCS) at $\mathrm{w}_{\mathrm{i}}=28.60 \%$

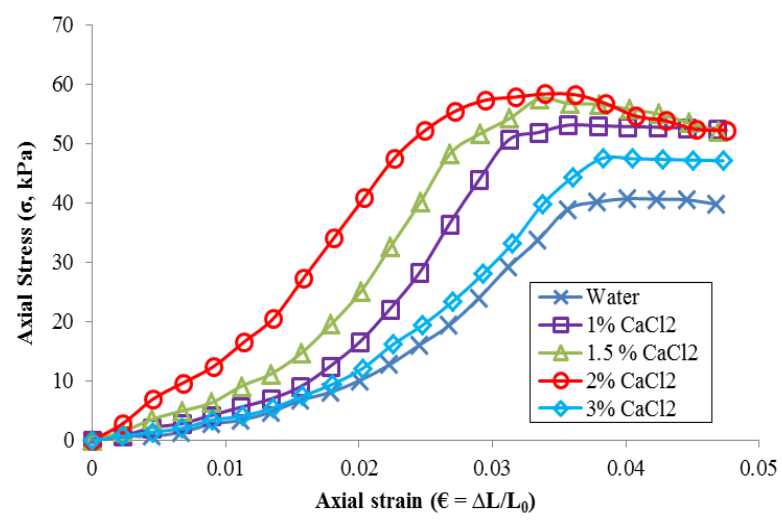

h) Soil C (100\%BCS) at $w_{i}=21.08 \%$

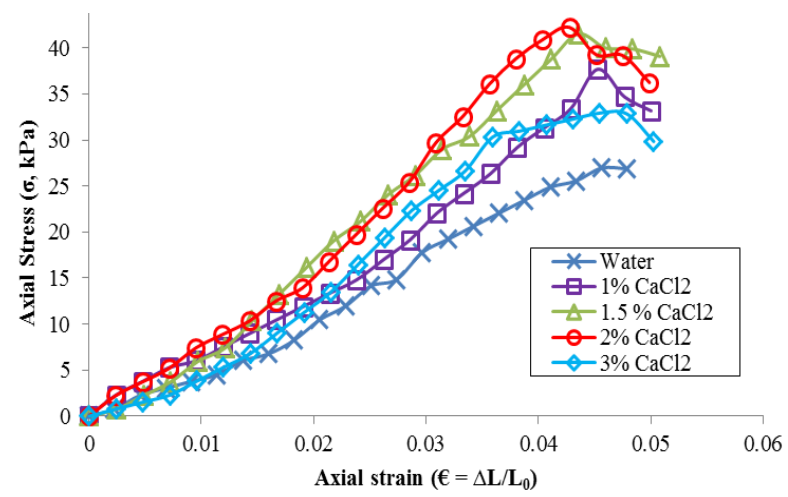

i) Soil C (100\%BCS) at $\mathrm{w}_{\mathrm{i}}=14.64 \%$

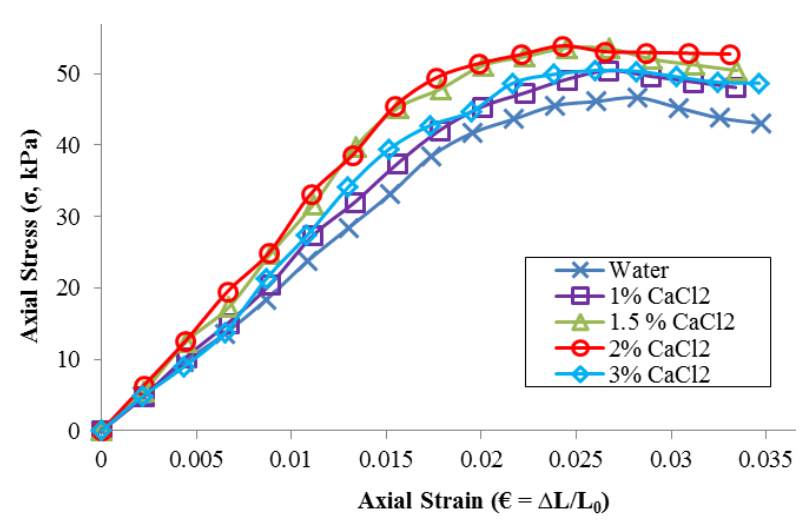

J) Soil D (BCS+20\%NSS) at $\mathrm{w}_{\mathrm{i}}=25.38 \%$

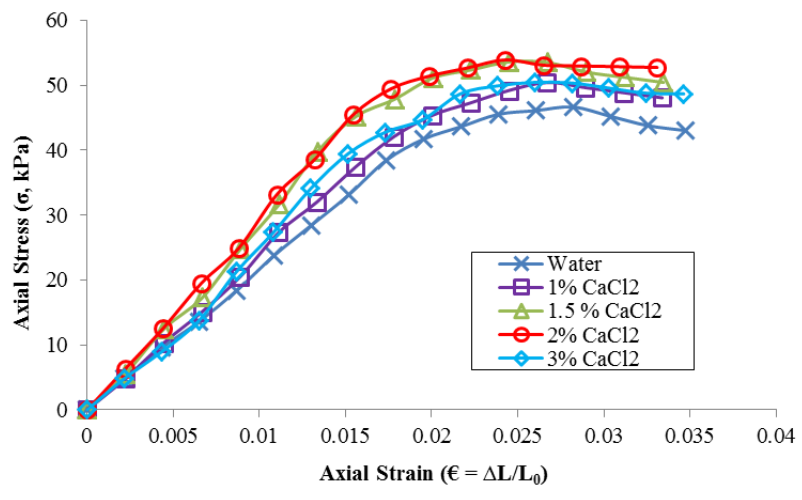

k) Soil D (BCS+20\%NSS) at $\mathrm{w}_{\mathrm{i}}=15.26 \%$

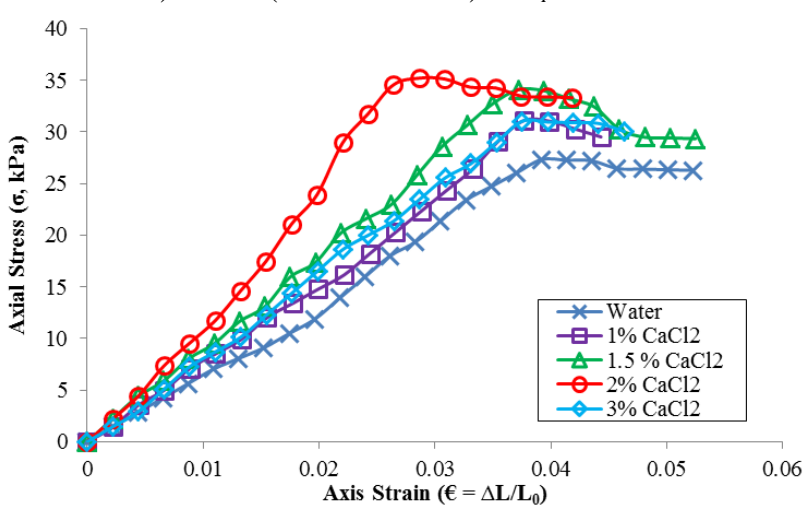

1) Soil D (BCS+20\%NSS) at $\mathrm{w}_{\mathrm{i}}=8.69 \%$

Fig 2 Stress-strain soil samples after diffusion of calcium chloride solution of different concentrations 

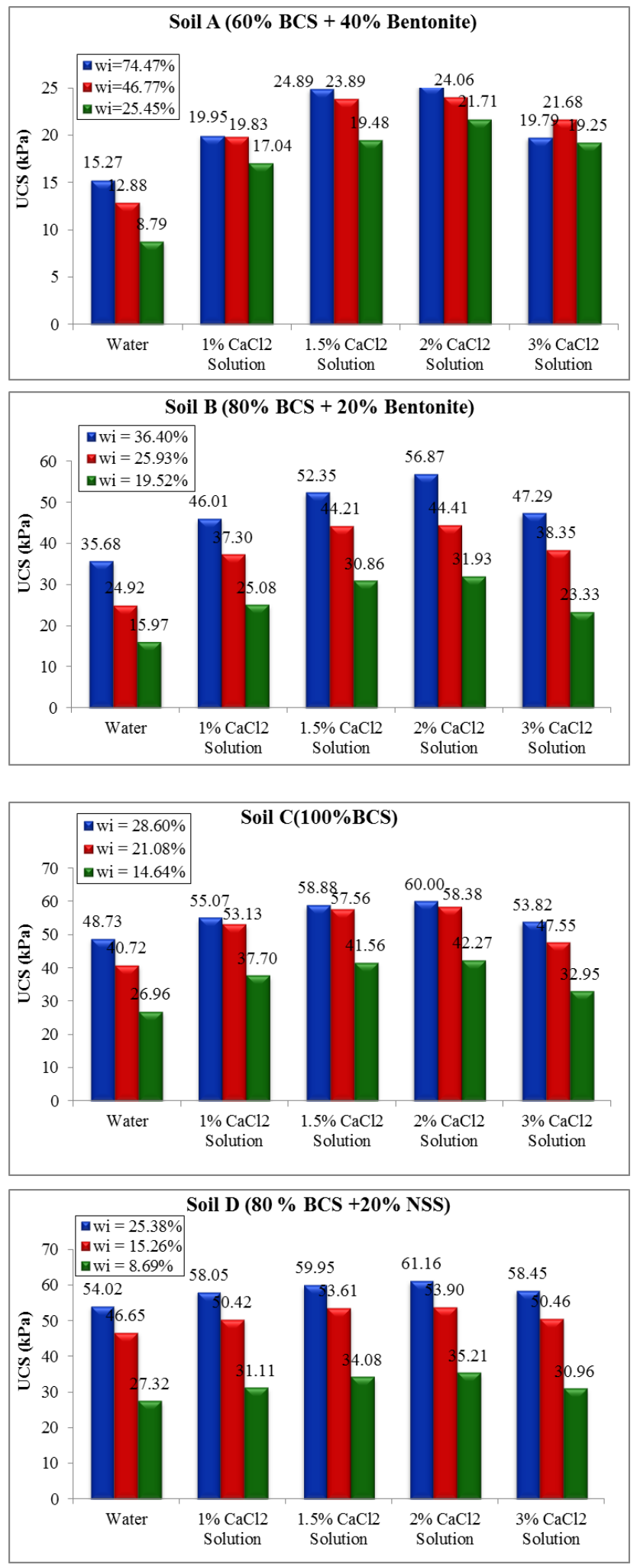

Fig 3 UCS $(\mathrm{kPa})$ of soil samples after diffusion of water and calcium chloride solutions
It is observed from the Table 3 the values of Unconfined compressive strength (UCS) increase with increase in initial water content $\left(\mathrm{w}_{\mathrm{i}}\right)$ and decrease in degree of swellability, considering the UCS of sample diffused by water as the base. The UCS values of samples treated by calcium chloride solutions are found to be increased substantially this is because soil become more stiffened due to chemical reaction between calcium chloride and clay mineral. It is also observed that the increased in calcium chloride concentration leads to an increase in the UCS (Unconfined compressive strength). The interaction of calcium chloride salt with the soil causes an increase in the ion concentration of the pore water with concomitant reduction in the double layer thickness and this in turn, causes a reduction in the antiparticles repulsion and an increase in the attraction, resulting in the increase in cohesion (Abood T. T. et. al. 2007). The results indicate that the maximum unconfined compressive strength is found in the soil treated Desai and Oza (1977) and some other investigators reported the positive results of calcium chloride in case of strength improvement. They reported that calcium chloride works not only by cation exchange but also by intercalation whereby calcium chloride enters into the intermiscellar spaces of clay mineral structure, thus bringing about significant modification in clay behavior. Numerous laboratory studies in the past have revealed positive effects of calcium chloride and lime on improvement of strength of expansive soil. The study presented in this research work substantiates this generally established fact in respect of in-situ expansive ground improvement by diffusion process also.
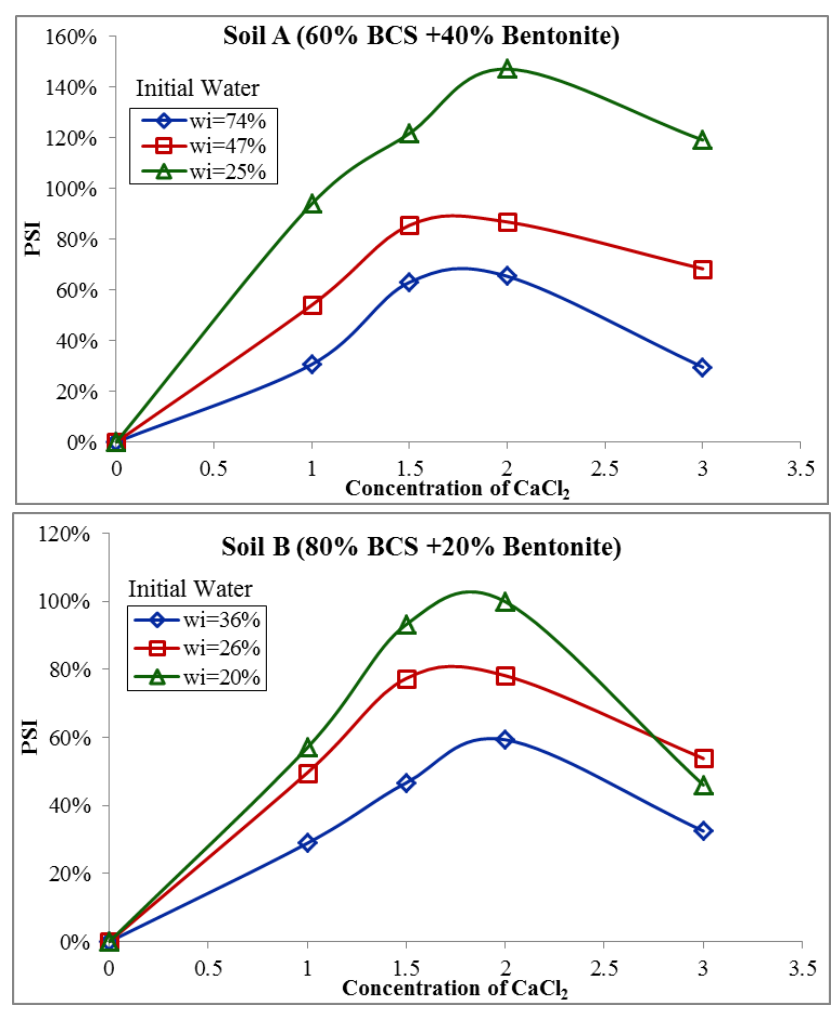


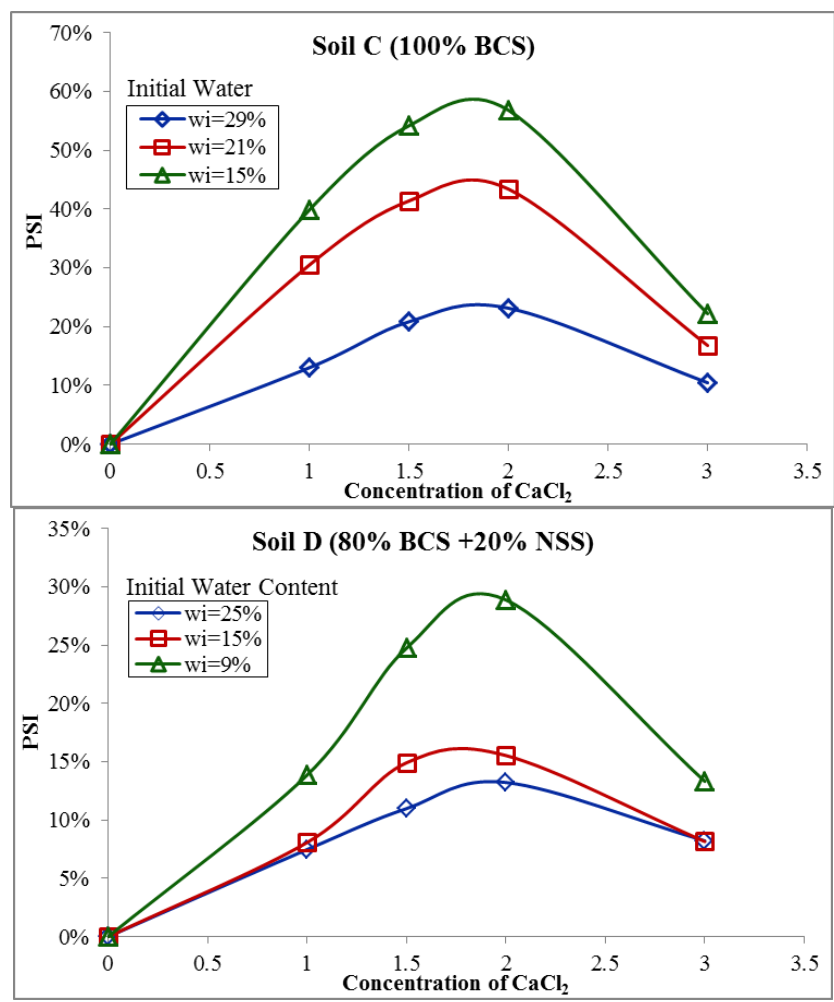

Fig 4 Variation of percentage strength improvement (PSI) vs concentration of $\mathrm{CaCl}_{2}$ solution

\section{Stiffness Behavior-}

Stiffness of the soil is the rigidity of soil or the extent to which it resists deformation in response to an applied force. It is defined as the force required for unit deformation of soil. Soil stiffness is commonly referred as soil elastic modulus and denoted by E. From stress-strain curves of Figure 2 it is observed that seating corrections in the curves of some of the soil samples is required. In such cases, the seating corrections are removed first by using the correction method given by Stark et al. (2004) and the stiffness at three different points are determined. As per this method, linear portion of the stressstrain curve is extended to bisect the horizontal axis by a straight line. The point where the straight line bisects the horizontal axis is considered as initial zero and stiffness are calculated accordingly at corrected strain levels. This may be due to the upper most layer of the soil sample which was get damaged when the sample is extracted after completion of diffusion process for UCS test. Hence the corrected stressstrain curve is drawn for each soil sample on applying correction at initial portion. Then the initial stiffness $E_{i}$, stiffness at $50 \%$ strength $\mathrm{E}_{50}$ and stiffness at failure $\mathrm{E}_{\mathrm{f}}$ are determined. Initial stiffness $E_{i}$ is the initial tangent modulus and it is an important parameter of soil which characterise the stiffness. It is determined as a slope of tangent drawn to the initial linear curve from origin. The stiffness at $50 \%$ strength
$\mathrm{E}_{50}$ is the secant modulus determined as a slope of a straight line joining origin to the point of $50 \%$ strength. Then the stiffness at failure point $\mathrm{E}_{\mathrm{f}}$ is determined from ratio of failure stress and the corresponding corrected value of strain. This so calculated stiffness's are reported in Figure 5.

Figure 5 (a) represents schematically, approach for determining the initial correction and determination of modulus of elasticity Ei, E50 and Ef. One representative case of soil samples is also shown in Figure 5 (b).

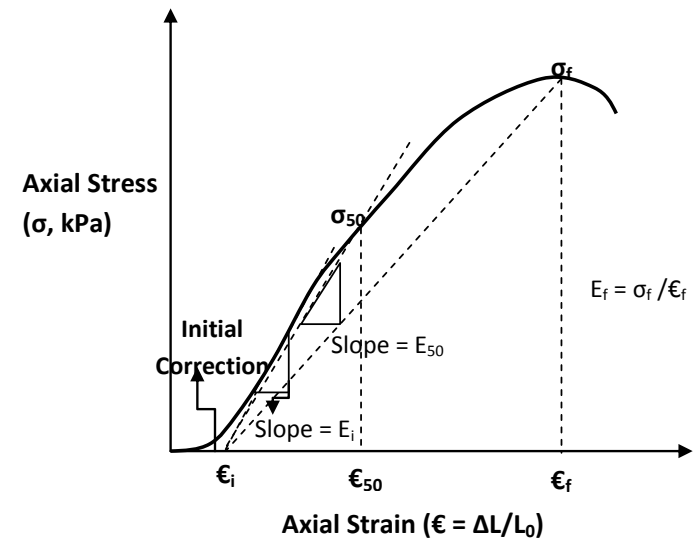

(a)

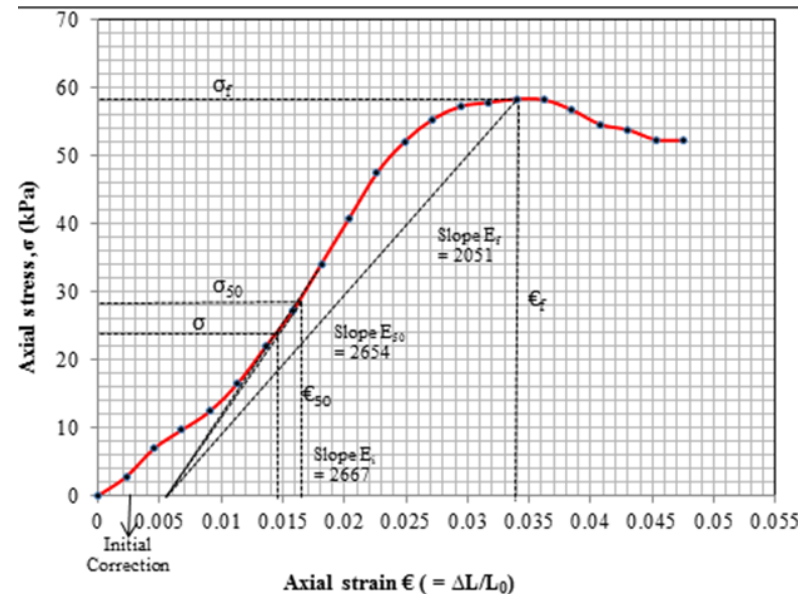

(b)

$\begin{array}{ll}\mathrm{E}_{\mathrm{i}} & =\text { Initial stiffness }=\text { Slope of initial straight portion } \\ \mathrm{E}_{50} & =\text { Stiffness at } 50 \% \text { strength }=\sigma_{50} / €_{50} \\ \mathrm{E}_{\mathrm{f}} & =\text { Stiffness at Failure }=\sigma_{\mathrm{f}} / €_{\mathrm{f}}\end{array}$

Fig 5 Schematic (a) sample case (b) diagram of stressstrain curve with initial correction

It is observed from the values of $E_{i}, E_{50}$ and $E_{f}$, the initial stiffness of all the soil samples is of highest value. Then the stiffness is decrease from initial stage up to the point of final stiffness at failure $\left(E_{f}\right)$. At the failure point the samples have lowest stiffness for each sample. As well as it is also observed that as the initial water content is decreases, stiffness of the soil sample after completion of diffusion process is decreases as shown in Figure 5. Stiffness (post diffusion) is also depends 
on the degree of swellability. It decreases with increase in degree of swellability.

The stiffness of soil sample is found to be increased due to diffusion of calcium chloride solution. The stiffness is increases with increase in concentration of calcium chloride solution up to $2 \%$ concentration. Thereafter the values of stiffness's are decreased for 3\% concentration as shown in Table 4.

Table 4: Stiffness of the expansive soft clay soil during UCS test after diffusion of calcium chloride solution of different concentrations

Soil A (60\%BCS+40\%Bentonite)

\begin{tabular}{|c|c|c|c|c|}
\hline Diffusing fluid & $\mathrm{W}_{\mathrm{i}}(\%)$ & $\overline{E_{i}}$ & $\mathrm{E}_{50}$ & $\overline{E_{f}}$ \\
\hline Water & \multirow[t]{5}{*}{74.47} & 1000 & 848 & 672 \\
\hline 1.0 & & 1538 & 1375 & 1027 \\
\hline 1.5 & & 1967 & 1857 & 1393 \\
\hline 2.0 & & 3222 & 3080 & 1638 \\
\hline 3.0 & & 1200 & 1099 & 997 \\
\hline Water & \multirow[t]{5}{*}{46.77} & 554 & 536 & 532 \\
\hline 1.0 & & 1636 & 1580 & 1028 \\
\hline 1.5 & & 2000 & 1990 & 1389 \\
\hline 2.0 & & 2000 & 1924 & 1361 \\
\hline 3.0 & & 1444 & 1354 & 1133 \\
\hline Water & \multirow[t]{5}{*}{25.45} & 494 & 462 & 358 \\
\hline 1.0 & & 1000 & 947 & 682 \\
\hline 1.5 & & 1414 & 1330 & 842 \\
\hline 2.0 & & 1429 & 1357 & 1075 \\
\hline 3.0 & & 1142 & 1069 & 765 \\
\hline
\end{tabular}

Soil B $(80 \% \mathrm{BCS}+20 \%$ Bentonite $)$

\begin{tabular}{|c|c|c|c|c|}
\hline Diffusing fluid & $\mathrm{w}_{\mathrm{i}}(\%)$ & $\mathrm{E}_{\mathrm{i}}$ & $\mathrm{E}_{50}$ & $E_{f}$ \\
\hline Water & \multirow[t]{5}{*}{36.40} & 1267 & 1200 & 1187 \\
\hline 1.0 & & 2286 & 2196 & 2054 \\
\hline 1.5 & & 3157 & 2908 & 2044 \\
\hline 2.0 & & 3078 & 3018 & 2396 \\
\hline 3.0 & & 2083 & 1970 & 1804 \\
\hline Water & \multirow[t]{5}{*}{25.93} & 1000 & 923 & 749 \\
\hline 1.0 & & 1333 & 1166 & 1072 \\
\hline 1.5 & & 1764 & 1637 & 1378 \\
\hline 2.0 & & 2307 & 2220 & 1493 \\
\hline 3.0 & & 1625 & 1474 & 1273 \\
\hline Water & \multirow[t]{5}{*}{19.52} & 400 & 398 & 389 \\
\hline 1.0 & & 875 & 783 & 740 \\
\hline 1.5 & & 1333 & 1143 & 1025 \\
\hline 2.0 & & 1600 & 1277 & 1071 \\
\hline 3.0 & & 725 & 706 & 644 \\
\hline
\end{tabular}

\section{Soil C (100\%BCS)}

\begin{tabular}{|c|c|c|c|c|}
\hline Diffusing fluid & $\mathrm{w}_{\mathrm{i}}(\%)$ & $\mathrm{E}_{\mathrm{i}}$ & $\mathrm{E}_{50}$ & $E_{f}$ \\
\hline Water & \multirow[t]{5}{*}{28.60} & 2500 & 2320 & 2117 \\
\hline 1.0 & & 2698 & 2622 & 2371 \\
\hline 1.5 & & 2879 & 2804 & 2514 \\
\hline 2.0 & & 2899 & 2850 & 2656 \\
\hline 3.0 & & 2636 & 2351 & 2165 \\
\hline Water & \multirow[t]{3}{*}{21.08} & 2000 & 1709 & 1622 \\
\hline 1.0 & & 2342 & 2214 & 1985 \\
\hline 1.5 & & 2616 & 2500 & 2234 \\
\hline
\end{tabular}

\begin{tabular}{|c|c|c|c|c|}
\hline 2.0 & & 2667 & 2654 & 2051 \\
\hline 3.0 & & 2272 & 1981 & 1958 \\
\hline Water & \multirow[t]{5}{*}{14.64} & 1079 & 999 & 736 \\
\hline 1.0 & & 1188 & 992 & 960 \\
\hline 1.5 & & 1250 & 1149 & 953 \\
\hline 2.0 & & 1390 & 1320 & 1216 \\
\hline 3.0 & & 1160 & 1067 & 890 \\
\hline
\end{tabular}

Soil D $(80 \%$ BCS+20\%NSS)

\begin{tabular}{|c|c|c|c|c|}
\hline Diffusing fluid & $\mathrm{w}_{\mathrm{i}}(\%)$ & $\mathrm{E}_{\mathrm{i}}$ & $\mathrm{E}_{50}$ & $\mathrm{E}_{\mathrm{f}}$ \\
\hline Water & \multirow[t]{5}{*}{25.38} & 3303 & 3000 & 1939 \\
\hline 1.0 & & 3341 & 3225 & 2206 \\
\hline 1.5 & & 3850 & 3747 & 2740 \\
\hline 2.0 & & 4563 & 4368 & 2815 \\
\hline 3.0 & & 3439 & 3247 & 2266 \\
\hline Water & \multirow[t]{5}{*}{15.26} & 2479 & 2332 & 1654 \\
\hline 1.0 & & 2620 & 2521 & 1888 \\
\hline 1.5 & & 3450 & 3154 & 2185 \\
\hline 2.0 & & 3950 & 3170 & 2221 \\
\hline 3.0 & & 2632 & 2522 & 1943 \\
\hline Water & \multirow[t]{5}{*}{8.69} & 824 & 758 & 697 \\
\hline 1.0 & & 987 & 818 & 779 \\
\hline 1.5 & & 992 & 947 & 916 \\
\hline 2.0 & & 1180 & 1141 & 999 \\
\hline 3.0 & & 902 & 861 & 781 \\
\hline
\end{tabular}

\section{CONCLUSIONS}

- The general features of the stress-strain curves are found to be similar for all the soil samples. The stress-strain behavior of the soil samples during diffusion is affected significantly due to concentration of calcium chloride solution, degree of swellability and initial water content of soil samples. It is also revealed that the failure stress for any soil increases with increase in concentration up to $2 \%$ concentration of calcium chloride solution. Higher concentration i.e. $3 \%$ results in comparatively lower values of failure stresses.

- Unconfined compressive strength (UCS) of expansive soil after completion of diffusion process also depends on initial water content and degree of swellability of soil mass. Its value decreases with decrease in initial water content and with increase in degree of swellability of the soil. The soil with high degree of swellability with its very low initial water content when treated with diffusion of calcium chloride solution of $2 \%$ concentration is found to exhibit maximum unconfined compressive strength.

- The percentage strength improvement (PSI) is also found to depend on initial water content, degree of swellabilty of soil mass and the concentration of calcium chloride solution.

Considering soils of different swellability and their respective initial physical states (i.e. ranging from nearer to almost dry state to nearer to saturated wet condition) when diffused by calcium chloride solutions of four different concentrations, the PSI for Soil A varies with in 


\section{International Journal of Engineering Applied Sciences and Technology, 2019 \\ Vol. 4, Issue 1, ISSN No. 2455-2143, Pages 67-77 \\ Published Online May 2019 in IJEAST (http://www.ijeast.com)}

a range of 32 to 147 whereas this range is 7 to 29 for Soil D.

- The stiffness of the treated soil by diffusion technique almost remains the same up to compressive strength of about $50 \%$ of the compressive strength of soil. Thereafter it reduces and at failure of soil it attains the minimum value. The difference between initial tangent modulus (Ei) and the secant modulus (E50) for all the four soils is very marginal.

- Similar to Unconfined compressive strength, the stiffness of expansive soil deposit after completion of diffusion process depends on initial water content and degree of swellability of the soil. The values of different stiffness modulii decrease with decrease in initial water content and increase in degree of swellability of the soil. The maximum stiffness modulus values are found in the soil with high swellability and its low initial water content when soil is treated by $2 \%$ concentration of calcium chloride solution.

\section{REFERENCE}

[1] Chen, F. H. (1988). "Foundations On Expansive Soils." Elsevier, Amsterdam, The Netherlands.

[2] Katti, R. K. (1979). "Search for solutions to problems in black cotton soils." First Indian Geotechnical Society Annual Lecture, Indian Geotechnical Journal, 9(1), (pp. 188).

[3] Petry, T. M. and Little, D. N. (2002). "Review of stabilisation of clays and expansive soils in pavements and lightly loaded structures-history, practice, and future." Journal of Materials in Civil Engineering, ASCE, 14(6), (pp. 447-460).

[4] Carreon D. G. (2006). "Stabilisation of marginal soils using recycled materials." Master of Science in Civil Engineering Thesis, University of South Florida.

[5] Cokca, E. (2001). "Use of Class C fly ashes for the stabilisationof an expansive soil." Journal of Geotechnical and Geoenvironmental Engineering, ASCE, 127(7), (pp. 568-573).

[6] Aparna, Jain, P. K. and Kumar, R. (2014). "Study of swelling behaviour of black cotton soil improved with sand column." International Journal of Advances in Engineering \& Technology, 7(3), (pp. 905-910).

[7] Nalbantoglu, Z. (2006). "Lime stabilisation of expansive clay." Expansive soils-recent Advances in Characterization and Treatment. London, Taylor I\& Francis Group, (pp. 341-348).

[8] Mohan, D., Jain, G. S. and Sharma, D. (1973). "Foundation practice in expansive soils in India." Proceedings of 3rd International Conference on Expansive Soils, Haifa, Israel, (pp. 319-324).
[9] Murty, V. R. and Praveen, G. V. (2008). "Use of chemically stabilized soil as cushion material below light weight structures founded on expansive soils, Journal of Materials in Civil Engineering, ASCE, 20(5), (pp. 392400).

[10] Phanikumar, B. R., Sharma, R. S., Rao, A. S. and Madhav, M. R., (2004). "Granular pile anchor foundation (GPAF) system for improving the engineering behavior of expansive clay beds." Geotechnical Testing Journal, ASTM, 27(3), (pp. 279-287).

[11] Sawant,V., Kumar, A. P. and Ranjan, G. (2010). "Granular anchor pile system for resisting uplift forces." Proceedings of Indian Geotechnical Conference, GEOtrendz-2010, Dec. 2010, IGS Mumbai Chapter \& IIT Bombay, India, (pp. 849-852).

[12] J. G. Khun, (1970). "Stabilisation of soil by diffusion of cations." United States Patent office, Daly City Calif., Patented Jan 20.

[13] Murty, V. R. and Krishna, P. H. (2006), Stabilisation of expansive clay bed using calcium chloride solution, Proceedings of Institution of Civil Engineers-Ground Improvement, 10(1), (pp. 39-46).

[14] Murthy, V. R. and Hari Krishna, P. (2007), Amelioration of expansive clay slopes using Calcium Chloride, Journal of Material and Science, ASCE, 19(1), (pp. 19-25).

[15] Kondekar, V. J. Jaiswal, O. R. and Gupta, L. M. (2013). "Geotechnical properties of stabilized ancient gadhi soil in Maharashtra State of India." Electronic Journal of Geotechnical Engineering,18(5), (pp. 5289-5302).

[16] Phanikumar, B. R., Ramesh, V. and Ramana Sastry, M. B. (1998). "Efficiency of calcium chloride in stabilising swelling soils." Procededing of Indian Geothecnical Conference, IGC-1998, Dec. 1998, IIT New Delhi, India, (pp. 245-246).

[17] Kesava, N. K. and Prasada Raju, G. R. (2011). "Evaluation studies of expansive soil treated with electrolytes." International Journal of Engineering Science and Technology (IJEST), 3(12), (pp. 8298-8306).

[18] Golait, Y. S., Lajurkar, S. P. and Bade, R. G. (2012). "Study of expansive clay stabilisation by diffusion of chemical solutions." Proceedings of Indian Geotechnical Conference, IGC-2012, Dec. 2012, Delh, India, (pp. 265268).

[19] Abood, T. T. Kasa, A. B. and Chik, Z. B. (2007). "Stabilisation of silty clay soil using chloride compounds." Journal of Engineering Science and Technology, 2, (pp. 102-110).

[20] Desai, I. D. and Oza, B. N. (1977). "Influence of anhydrous calcium chloride on the shear strength of expansive soil." Procededing of $1^{\text {st }}$ National Symposium on Expansive Soils, HBTI-Kanpur, India. 
International Journal of Engineering Applied Sciences and Technology, 2019

Vol. 4, Issue 1, ISSN No. 2455-2143, Pages 67-77

Published Online May 2019 in IJEAST (http://www.ijeast.com)

[21] Stark, T. D., Arellano, D., Horvath, J. S. and Leshchinsky, D. (2004). "Geofoam Application in Design and Construction of Highway Embankments." Transportation Research Board, Washington, D. C., USA, NCHRP 529, 71 pages. 